\title{
NACISTICKÁ OKUPACE V NOVELE JANA OTČENÁŠKA „ROMEO, JULIE A TMA“ A VE FILMOVÉ ADAPTACI JIŘÍHO WEISSE
}

\author{
PETR KUČERA
}

KUČERA, Petr: Nazi Occupation in the Novel "Romeo, Juliet and Darkness" by Jan Otčenášek and in the Film Adaptation by Jiř́ Weiss, 2019, Vol. 1, Issue 1, pp. 76 - 85. DOI: 10.17846/CEV.2019.01.1.76-85.

\begin{abstract}
The article deals with the comparative analysis of Jan Otčenášek's prose Romeo, Julie a tma (Romeo, Juliet and Darkness, 1958), and the film adaptation of director Jiři Weiss (1959). The writer and director co-wrote the script - when they came to film adaptation, they sought to make changes to the text of the prose, which would allow the language of the film to best express the disturbing atmosphere of the period of Nazi occupation in Prague. Prose and film are the prologue of the "golden sixties" years of Czech literary and film - in addition to the short stories published at the same time by Arnošt Lustig, they begin a stage of literary and film interest in Jewish fate under the conditions of the Nazi occupation regime in the Czech part of the former Czechoslovakia. On the ground plan of the famous tragedy of W. Shakespeare, J. Otčenášek created a love drama from the darkest period of the 20th century - film adaptation, the story dynamises and highlights the moral dilemma of people who have had to take a clear stance in the face of the fate of the Jews.
\end{abstract}

KEYWORDS: Czech Prose of the Late 1950s and 1960s. Psychological Prose. New Wave of Czechoslovak Film. Second World War. Nazi Occupation. Jewish Themes. Jan Otčenášek. Jiří Weiss.

Nacistická okupace znamenala pro českou kulturu období největšího existenčního ohrožení. Vznik Protektorátu Čechy a Morava a obsazení historických zemí Koruny české hitlerovskými vojsky dále stupňuje cenzurní zásahy, k nimž docházelo již v roce 1938. Hitlerův nacionální socialismus likvidoval nejprve českou inteligenci a levicově nebo demokraticky orientované spisovatele a umělce (zatýkání tzv. nespolehlivých, popravy, zavření vysokých škol, deportace studentů do koncentračního tábora v Sachsenhausenu aj.). Relativně dobře se dařilo apoliticky laděné zábavě, kterou bylo možné propagandisticky zneužívat, protože budila zdání normálnosti života v okupované zemi. Zájmu nacistických ideologů se těšila především filmová tvorba, nebot film byl chápán jako nové médium, které může účinně oslovovat široké vrstvy obyvatelstva. Nacisté ovládli filmová studia, v Praze na Barrandově byly i díky otrocké práci Židů postaveny na svou dobu mimořádně rozsáhlé ateliéry. Točily se zde německé propagandistické filmy a české filmové komedie, popř. nekonfliktní historické a milostné snímky.

Po 2. světové válce se $\mathrm{v}$ české kultuře vzedmula vlna válečné prózy, která se zaměřovala na svědectví o hrůzách šoa. Tato literatura zdưrazňovala faktografickou přesnost při popisování nacistického teroru a autenticitu prožívání postav. K hlubšímu ponoru do psychiky obětí i pachatelů, $\mathrm{k}$ hledání přičcin a souvislostí největší genocidy v dějinách Evropy však bylo nutno získat větší časový odstup. Zde lze hledat také jednu z př́čin zaostávání prózy za poezií a dramatem, o němž se zmiňuje Jiří Holý (Lehár et al. 1998, 763): „Bylo to pochopitelné, nebot zejména román bývá bezprostředně spojen $s$ myšlenkovým a politickým ruchem doby. Proměnlivé ovzduší konce padesátých a počátku šedesátých let, kdy ,oteplení vzápětí vystř́ídala restaurace stalinismu a kdy byla kultura stále prrísně stř̌ežena cenzurou, svědčilo kratším a aktuálně působícím žánrům: črtě, povídce, novele."

Nový prŕstup k válečným tématům tak přináší až tzv. druhá vlna české válečné prózy na přelomu padesátých a šedesátých let (k první a druhé vlně viz blíže Machala 2015, 369 - 378). S druhou vlnou válečné prózy přichází i proměna oficiálně vyžadované metody socialistického realismu. 
Aleš Haman chápe novou, psychologizující větev válečné prózy jako tzv. druhou vlnu, v níž se autoři snaží skloubit v jediném obraze individuální analýzu psychiky postav s pohledem na celkový pohyb společnosti. ${ }^{1}$ Počátek nového směřování české prózy zahájil Edvard Valenta románem Jdi za zeleným světlem (1956) - vyprávění již není zprostředkováno pouze vševědoucím vypravěčem, ve vnitřních monolozích hlavní postavy se vyjevuje složitost psychiky moderního člověka. Hrdinou již není dělník, ale intelektuál ocitající se v kritické existenciální situaci, který pochybuje o vnucovaných pravdách i o sobě samém.

Pozoruhodným „osmičkovým“ letopočtem v dějinách české poválečné prózy je rok 1958, kdy vychází několik próz, jaké si do té doby nebylo možné v oficiálně vydávané literatuře představit. Jednoznačný rozchod s komunistickou ideologií představuje generační román Josefa Škvoreckého Zbabělci (1958). „Jazzově“ cítící a vůči oficiálním ideologickým manipulacím zcela rezistentní Danny Smiřický zahajuje vzpouru nejen proti černobílému výkladu nedávných dějin, ale také proti sešněrovanému životnímu stylu vnucovanému mladé generaci. Dobová recepce románu výmluvně ilustruje rozvolňování kritérií, jimiž byla do té doby svazována oficiální kultura. Vydání románu v nakladatelství Československý spisovatel a příznivé recenze v liberálněji řízených periodikách vyvolaly pobouřené reakce stranického tisku a nejvyššího vedení komunistické strany - výsledkem bylo stažení všech výtisků románu z prodeje i z veřejných knihoven. Nastupující proměnu i části oficiálně vydávané tvorby však již nebylo možné stranickými př́kazy a zákazy zastavit (srov. Holý 1998, 763 - 764).

V nově vznikající próze je patrný především ústup od pojetí historie jako sledu politických událostí a heroizace jejich aktérů - nejvýrazněji se tento odklon od tzv. velkých dějin projevil $\mathrm{v}$ části válečné prózy, která se obrací ke každodennosti malého člověka, jeho niterným obavám, touhám, ale i ke všednosti, banalitě a dokonce trapnosti života, který je pouhým obstaráváním a přežíváním. Novou typologickou linii představuje próza tematizující židovský osud, nebot Židé byli nejčastějšími obětmi nacistického teroru. Židovská tematika je však zároveň více či méně skrytou polemikou s komunistickým režimem, který byl výrazně antisemitský - v obnažené podobě se tento rys nového totalitního režimu projevil v popravách Židů v politicky inscenovaných procesech v první polovině padesátých let.

Umělecky nejvýraznějšími autory české válečné prózy s židovskou tematikou jsou Arnošt Lustig (1926 - 2011), Josef Škvorecký (1924 - 2012) a Ladislav Fuks (1923 - 1994). Díla těchto autorů byla přeložena do desítek jazyků a dočkala se i řady filmových, televizních a divadelních adaptací. Velkému zájmu filmařo se $\mathrm{v}$ šedesátých letech těšily zejména prózy Arnošta Lustiga. Podle povídek Noc a naděje (1957) natočil Zbyněk Brynych film Transport z ráje (1963); podle povídky Tma nemá stín z povídkové sbírky Démanty noci (1958) natočil Jan Němec stejnojmenný film (1964). Antonín Moskalyk adaptoval v roce 1965 pro televizi Lustigovu novelu Modlitba pro Kateřinu Horovitzovou (1964), v roce 1967 pak zfilmoval novelu Dita Saxová (1962). Josef Škvorecký věnoval židovské tematice povídkové knihy Sedmiramenný svícen (1964) a Babylonský př́běh a jiné povídky (1967). Vojtěchem Štursou byla v roce 1997 zfilmována Škvoreckého novela Legenda Emöke (napsaná v roce 1958 a vydaná v roce 1963). Václav Gajer natočil film s názvem Flirt se slečnou Stříbrnou v roce 1969 podle Škvoreckého román Lvíče (1969). Ladislav Fuks vytvořil $\mathrm{v}$ šedesátých letech řadu próz reflektujících téma židovského osudu v období nacistické okupace - román Pan Theodor Mundstock (1963), sbírku povídek Mí černovlasí bratři (1964),

Bliže k tzv. druhé vlně srov. studii Haman, Aleš, 1961. O tak zvané „druhé vlně“ válečné prózy v naší současné literatuře. In: Česká literatura, roč. 9, č. 4, 513 - 520. 
román Variace pro temnou strunu (1966) či novelu Spalovač mrtvol (1967). Podle této novely natočil v roce 1968 Juraj Herz stejnojmenný film. ${ }^{2}$

V mezinárodním kulturním kontextu méně známá, v českém prostředí však důležitá je tvorba Jana Otčenáška (1924 - 1979). Jeho prozaická tvorba spojená s žánrovou formou budovatelského románu poznamenala i jeho další prózy respektováním metody typizace, která je jedním z podstatných rysů tvůrčí metody literárního a uměleckého směru socialistického realismu (Janoušek a kol. 2012, 142): „V žánru budovatelského románu se [...] projevovala jedna z klíčových norem socialistického realismu, totiž požadavek typizace jako výraz představy, že tvůrce nemá $\mathrm{z}$ chaosu jevového světa vybírat věci a jevy zdánlivě statisticky významné, ale to, co je podle jediného správného, vědeckého výkladu světa zárodkem rodící se ideální budoucnosti. Vycházelo se z předpokladu, že tvůrci nebo kritici jsou schopni takovéto jevy rozpoznat [...].“

Otčenáškovu prozaickou tvorbu z padesátých let lze ke směru socialistického realismu nepochybně přiřadit, cele postihnout ji však tímto směrem nelze. Již Otčenáškův románový debut Plným krokem (1952) na jedné straně naplňuje poetologické charakteristiky žánrové formy budovatelského románu, na druhé straně se přece jen od děl tohoto typu liší zájmem o dramata, která se odehrávají v nitru postav. Také románem Občan Brych (1955) Otčenášek naplňoval, ale částečně i problematizoval principy socialistického realismu - zejména ve tvárném postupu typizace (Janoušek 2012, 148): „Všechny postavy této prózy jsou tak nadále typovými reprezentanty sociálních sil a vývoj hrdiny je spíše formální, potvrzující předem daný výsledek. Nicméně dobový př́nos Otčenáškova románu byl v tom, že se autor pokusil vrátit $\mathrm{k}$ psychologičtějšímu pojetí prózy, ve kterém je středem vypravěčského zájmu jednotlivec a jeho nitro, přičemž takový nový hrdina má právo i na chyby a dočasné omyly - pokud se nakonec rozhodne ,správněe““

Výraznější rozchod Jana Otčenáška s oficiálními schématy představuje jeho próza Romeo, Julie a tma (1958). Tato novela s tragickou milostnou zápletkou byla krátce po vydání představena divákům jako divadelní inscenace; následujícího roku se dočkala také filmové adaptace v podobě černobílého celovečerního filmu. V tvorbě Jana Otčenáška jsou intermediální dispozice neobyčejně silné, o čemž svědčí řada divadelních, rozhlasových, filmových a televizních adaptací jeho prozaických děl (blíže srov. Blažíček 1998, 159 - 161).

Aluze na Shakespearovu světoznámou tragédii mívají u autorů vycházejících z pozic realismu zpravidla hlubší společensko-kritickou motivaci. Tak např. významný představitel tzv. poetického realismu v německy psané literatuře, švýcarský prozaik a básník Gottfried Keller (1819 - 1890), staví ve své nejpřekládanější novele Romeo und Julia auf dem Dorfe (Romeo a Julie na vsi, 1874) mladým milencům oproti rodovým (a skrytě i náboženským) překážkám alžbětinské doby překážky nové: pokřrivené pojetí cti a vzájemnou nevraživost rodin soupeřících v období divokého kapitalismu o kus pole; uprostřed nádherné švýcarské prŕrody, avšak v bezvýchodné rodinné a společenské situaci spáchají mladí milenci společnou sebevraždu.

Jan Otčenášek se neuchyluje k Shakespearově dramatu jako k prototypu milostné tragédie v sociálně nepříznivém prostř̌edí, ale jako první (vedle Arnošta Lustiga) si v české próze padesátých let všímá nikoli nemožnosti žít plnohodnotný život, ale nemožnosti uhájit jako Žid v podmínkách zrůdného rasistického režimu holý život. Ne již pouhé předsudky v rodině, společenské vrstvě apod., ale všudypř́tomná tma je protivníkem milenců - tma smrti, která na evropské Židy v době 2 . světové války číhala všude.

Jan Otčenášek vyniká nejen fabulační schopností či citem pro dramatický dialog a gradaci napětí v akčních scénách. V lyricky laděných líčeních dobové atmosféry dokáže ve zkratce vystihnout momenty, které propojují pocity okouzlení či dojetí se soucitným pohledem na aspekty

2 Blíže srov. studii Kučera, Petr: Spalovač mrtvol Ladislava Fukse ve filmové adaptaci Juraje Herze. In: Timko, Štefan (ed.): Česká literatura a film V. Nitra: UKF, 2018, 54 - 75. 
ubohosti nebo trapnosti zobrazované skutečnosti - Otčenášek (2014, 10 - 11): „Samozřejmě: je válka, Němci ohryzali hranice a ted'se rozvalují v celé zemi. Zprávy o vítězstvích na souši, ve vzduchu i na moři doprovázené bubny neberou konce. Říká se tomu Protektorat für Böhmen und Mähren, ale starý Čepek důsledně jmenuje tenhle vypráskaný státeček - protentokrát. Kobylky egyptské! lomí rukama máma. Pro každou príležitost snadno najde př́měr v biblickém příběhu. V boudě abys bifloval životopisy nacistických svatých, nechceš-li spolehlivě proletět před německým inspektorem při mature. Also, sagen Sie mir, wo wurde Adolf Hitler geboren? Und jetzt etwas über das Winterhilfswerk! Hrdinná wehrmacht potopila zase tolik a tolik brutto registrovaných tun a táhne na Moskvu, nemáš si kam jít zatančit a v biografu si div sanice nevykloubiš zíváním při nekonečném týdeníku, který praská chvastounstvím a láskou k führerovi."

Dříve běžné heroizaci kladných hrdinů se Otčenášek systematicky brání poukazy na obyčejnost, až ubohost existence těchto postav. Tak kupř. Pavlův otec je líčen jako přepečlivý krejčík - drobný živnostník, který se chová poníženě vůči zákazníkům, ale dokáže neokázale pomoci Pavlovi s jídlem pro ukrývanou židovskou dívku Ester. Krejčovský tovaryš Čepek, který je zdánlivým prototypem úzkoprsosti a osaměleckých tiků, zas dokáže Ester zachránit před vpádem kolaboranta Rejska, který ji chce vyhnat z komůrky za krejčovskou dílnou.

Výraznou tendenci k typizaci postav a jevů, známou z próz $\mathrm{v}$ duchu socialistického realismu, proměňuje Otčenášek kontrastním relativizováním v účinný prostředek analýzy rozmanitých podob chování postav obyčejných lidí v době okupace. Tvrdí-li např. Karel Komárek $(1994,277)$, že „schematické rozvržení charakterových rysů mezi hlavní postavy autorovi nedovolilo překročit hranice jistého ideového apriorismu spjatého s koncepcí tzv. socialistické literatury“, má pravdu jen zčásti. Také zde se totiž projevuje jistá ambivalentost Otčenáškova uměleckého myšlení - metodu socialistického realismu zároveň naplňuje i narušuje.

Narušování ideových stereotypů napomáhá také Otčenáškova oblíbená hudební kompozice próz - nejčastěji v duchu symfonické skladby. Metoda kontrapunktu jednotlivých pasáží textu, připomínajících symfonické věty, je umocněna vytržením čtenáře $\mathrm{z}$ toku napínavého děje prostřednictvím lyrických ponorů do vzpomínek, snových představ či psychologizujících reflexí. Tyto pasáže používá Otčenášek k odplavení emocí bolesti, vzteku, bezmoci či bezradnosti, které čtenář s postavou Pavla spoluprožívá, ale také k již zmíněné relativizaci hodnot dosud vnímaných jako bezproblémově jednoznačné. Pavel tak přirozenou cestou vlastní zkušenosti dospívá k poznání neužitečnosti racionálního rozhodování v situaci, kdy jsou v sázce nejvyšší lidské hodnoty.

V působivých zkratkách načrtnutá fenomenologie strachu v kritické individuální a zároveň celospolečenské situaci nevrcholí v Otčenáškově novele prozřením, zmoudřením nebo urychleným dozráním hlavní postavy. Zásadní etické problémy odpovědnosti za druhé lidi nebo odvahy k překonání stereotypů diktovaných racionální úvahou si ponechávají i nadále svou naléhavost a složitost, autor nepřebírá odpovědnost za jejich řešení. Podoby kolaborace $s$ nacistickým režimem, stejně jako podoby nenápadného hrdinství vyvstávají před čtenářem ve své konkrétnosti a výraznosti. V jemných náznacích se odehrávají i cudné scény milostného sbližování Pavla $s$ Ester, které ve spojení s proudem lyrického komentáře přerůstají v podobenství o nezničitelnosti lásky a její životodárné síly i za hranicemi fyzického bytí milované osoby.

Protektorátní reálie vstupují do textu nenápadně, filtrem důsledné osobní zkušenosti. Obraz života za okupace je tak - navzdory autorovu soustředění na milostnou tragédii - překvapivě pestrý. Detaily z každodenních obtíží s obstaráváním základních životních potřeb (nedostatek jídla přidělovaného na lístky, nedostatek a nízká kvalita látek v krejčovské dílně Pavlova otce, zábava omezená na propagandou deformovaná filmová představení, nejrůznější omezování osobní svobody, zatemňování oken apod.).

Nejhorší je však situace Židů, kteří nesmějí chodit do žádných škol nebo veřejných zařízení, jako jsou divadla, kina, kavárny atd., ale ani do parků, nesmějí jezdit žádnými dopravními 
prostředky, mají ještě nižší příděly potravin atd. Tyto informace vyplývají průběžně z rozhovorů a zkratkovitých zmínek vypravěče jako fakta, která nejsou hodnocena či dramaticky akcentována, působí však na čtenáře nečekaně silně, nebot’ v české kultuře období komunistického režimu chybí tradice zobrazování židovské tematiky.

V Československu sice nedosahoval antisemitismus takové intenzity jako v Sovětském svazu, kde docházelo $\mathrm{k}$ masovým vraždám židovských spisovatelů a intelektuálů, rozhodně však nebyl zanedbatelný. Zvlášt výrazná byla tato tendence $\mathrm{v}$ padesátých letech, kdy byli společensky aktivní Židé odsuzováni ve zinscenovaných procesech $\mathrm{k}$ trestu smrti nebo k mnohaletému vězení, což většinou znamenalo smrtelně nebezpečnou práci v uranových dolech. V tomto kontextu je nutno chápat Otčenáškovu novelu jako odvážný pokus o tematizaci židovského osudu v oficiálně vydávané české literatuře. Šedesátá léta lze pak do jisté míry označit za období detabuizace židovské tematiky, avšak pouze z období nacistické okupace. Teprve po roce 1989 dochází k připomínání temných stránek našich dějin, jimiž bylo např. domácími profesními komorami požadované propouštění židovských lékařủ a právníků ze zaměstnání ještě před začátkem nacistické okupace.

Janu Otčenáškovi se v novele Romeo, Julie a tma daří nejen v tematické rovině, ale také v rovině jazyka a stylu něco, co bychom od oficiálně vydané prózy v dané době nečekali - navrací zkušenost zpátky do literárního jazyka (Otčenášek 2014, 63): „Nevnímal vlastně nic kolem sebe, utopen ve zlých starostech. Zpočátku si predstavoval - bláhovec - všechno jednodušší. Tady jsme: ona a já! Ale záhy se ukázalo, že jen uživit v téhle bídě osmnáctiletého člověka je obtižný úkol a že nestačí jen denně oddělovat ze svého talíre chudou porcičku a tajně ji pronášet před zraky rodičů, nemají-li oba zeslábnout hlady. [...] Hlad! Byl to ponižující, trapný pocit, jaký v životě nepoznal. A ted často cítil, jak mu při nejmenši námaze, třeba při běhu do schodì, vyráží po těle pot slabosti, jak se mu zachvívají ruce, jak měknou nohy v kolenou a žaludek svíravě pobolívá, jak dál?"

Toto navracení zkušenosti zpátky do jazyka není dáno vnějšími okolnostmi autobiografického zaměření díla či důkladné znalosti doby a prostředí - vyplývá ze záměrného odstraňování překážek, které totalitní režimy kladou do cesty přirozenému světu. Ve sféře jazykové komunikace je to především snaha o depersonalizaci jazyka, jeho maximální odlidštění, které má zakrýt antihumánní povahu daného politického režimu. Otčenáškův vypravěč i milenecká dvojice jemně vnímají vše násilné, nepřirozené, svazující - nikoli však v rovině ideologických konstruktů, proti nimž by stavěli jiné konstrukty. Jejich vnímání a prožívání se odehrává v rovině intenzivně žité zkušenosti. V tomto smyslu je hlavním hrdinou díla lidskost jako projev nejvyšší úcty k životu a touhy po jeho naplnění v přirozeném světě - (Otčenášek 2014, 65): „Táto! Co mi můžeš ř́ci? Nic! Bojím se tvého strachu, sám svůj sotva unesu, bojím se tvých očí. Bojím se tvého rozumu, táto. Mluvil bys o rozumu, ale co je mi ted’ platný? Co je vlastně rozum? Kde je? Máš ho ty? Mám ho já? Já nevím, táto! Rozumem bych ji mohl jen a jen vyhnat. Vypudit ji zúkrytu. Snad i - zabit. Mohl bych si snad říci: v sebeobraně. Tišs a promyšleně. A pak ji vzít do náručí, odnést ji ve tmě a přehodit zbaběle přes hřbitovni zed. Jinde by ji už nepríijali. Ona už nikam a nikomu nepatři. Jen mně.

A tmě.“

Tma je nejen všudypř́tomnou kulisou danou ustavičným zatemňováním a ukrýváním, ale především metaforou celého válečného období, v němž dosud nepoznaným způsobem prohrávají humanitní ideály, jimž zasvětily svůj život velké mravní osobnosti meziválečného Československa. Temnotu jako základní charakteristiku doby připomíná ve svých denících jeden z největších talentů české poezie dvacátého století, židovský básník Jiří Orten (1919 - 1941), jehož život ukončilo smrtelné zranění, které utrpěl několik týdnů před začátkem transportů Židů do koncentračních táborů při srážce s německou sanitkou - 2. června 1940 si do Žihané knihy, jak nazval třetí sešit svých deníků, poznamenal (Orten 1993, 116): „Žil jsem v čase velikého stmívání světa, na to at nikdo z lidí nezapomene, až mne jednoho dne potkaji!“ 
Ve snaze proniknout co nejhlouběji do psychického světa ústřední dvojice využívá Jan Otčenášek zobrazování snových představ. Tento postup rozšířil v moderní době významně možnosti novelistického žánru, nebot ho více druhově znejasnil (přibližil více k lyrice), a tak usnadnil komunikování obsahů jiného typu. Autor zachycuje sen poslední noci před maturitní zkouškou (Otčenášek 2014, 107 - 108): „Dál, vydrž! Ještě pár kroků, zatít zuby, výš! Pak si s výkřikem leknutí povšiml, že skálu oblétá pták, snad sup, snad orel gigantických rozměrư. Stín rozprazǎených kř́del jí ulehl na tvář. Zahlédla jeho oči. Byly to lidské oči. Odkud je znám? Stál na posledním schodě, křečovitě se držel levičkou železné skoby, pravičkou svíral její ruku. Visela nad jícnem propasti, otáčejíc se kolem své osy, na chatrném kabátku oslnivě svitila hvězda. Z šedavých hlubin opèt vzlétl pták. Povšiml si, že místo dravčích spárư má lidské ruce. Jimi ji uchopil za nohy a táhl dolù, rval je od sebe strašnou silou. Nevydržím! Hleděli na sebe, pohybovali naprázdno ústy, všechna slova byla spotřebována. Jen oči zbývaly. Pak si všiml, že už nemá oči. Jen dva černé otvory a v nich tmu."

Zdánlivý paradox Otčenáškova uměleckého př́nosu v novele Romeo, Julie a tma, který spočívá ve funkčně využité lyrizaci a dramatizaci epického tvaru, je očistným návratem k tradici novely jako žánru oscilujícího mezi literárními druhy. Vedle tematického novátorství (již zmíněné uvedení tabuizované problematiky židovského osudu do české prózy) je nutno zmínit také autorovo úsilí stylotvorné. V Otčenáškově literárním stylu lze najít některé rysy schematismu prózy tzv. socialistického realismu, za důležitější však považuji jeho snahu o vymanění se z tendenčnosti. Pasáže, v nichž dramatičnost situace graduje, kombinují např. na minimálním prostoru vizuální a smyslové vjemy s neobvyklými obrazy vnitřních pocitů postavy (Otčenášek 2014, 154 - 155): „Dosud ji nespatřili a byli pokojní. Dosud...

Povely v mozku: Ted... ted!

Uštvaně se rozhlédla. Kam? Nedýchajíc, zády ke zdem a staženým roletám výkladi̊, sunula se k nároží. Dva tři kroky! Krok... ještě... podivné, že si jí dosud nevšimli, že nezaslechli hlasitý buchot srdce. Zvláštní pocit: vystoupila ze sebe samé, mrákotný strach ji vyštval z vlastní kůže, jakési cizí těleso se plazí za širokými, šedozelenými zády, a ona je sleduje ze snového odstupu. Ne, to se jí netýká, to není pravda... Pavle - kdybys to vidèl!

Krok... nároží!

Nohy ji zradily. Samy vyrazily v bezhlavém útěku, poháněny nesmyslnou energií strachu... tady je nároží - nesly neživé tělo úzkou uličkou... pryč, pryč! zavřená vrata, zatemněná okna..."

Otčenáškova mimořádná senzitivita $\mathrm{k}$ vizuálním a akustickým vjemům, která je patrná v celém textu novely, poskytuje filmovým tvưrcům řadu možností ke ztvárnění komorního dramatu, které není jen milostným př́během, ale vypovídá zároveň leccos podstatného i o atmosféře válečné doby. Novelistický žánr také nejlépe vyhovoval Otčenáškovu lyricko-dramatickému naturelu, v němž se snoubí schopnost myšlení v obrazech s citem pro hlubší dramatický konflikt, který autor dokázal postřehnout i v nenápadných každodenních situacích. Právě v nich se vyjevuje propojení privátního a společenského, které v době největšího nebezpečí získává podobu boje o vlastní přežití. V protektorátním režimu se jako úspěšná strategie přežití osvědčil izolacionismus. Zapouzdření se do vlastního mikrosvěta vyžadovali nacisté od obyvatel okupovaných území, nebot' izolované jedince bylo možné celkem dobře ovládat, soudržné skupiny však podstatně hůř̌e. Nesnesitelná se Pavlovi jeví lehkost, s níž lidé zavírali oči nad židovským osudem (Otčenášek 2014, 158): „Ty musíš žít, zaslechl v sobě hlas. Zná jej.

Leží dosud naznak, pootevřenýma očima civí do okna. V̌̌ední den se za ním klube z předjitřních červánků, obyčejný den na konci príběhu.

Stokrát se vracel po jeho niti zpět k oné nenápadné lavičce v parku a zase vpřed až k nepochopitelnému okamžiku... Nic se vlastně nestalo: vzal za kliku, vstoupil.

Pokoj byl prázdný! Nic! 
Vlastně ani potom se nic nestalo. Zbylo jen hledání cesty, hmatání v prázdnotě. Otázky bez odpovědi. Proč všichni mlčí? Lidé i věci mlčí. Proč se nic nestalo? Proč se všechno vrátilo do bahnitých kolejí, ztuplo v plesnivém vzduchu protektorátu? Proč se nezřitila obloha?"

Filmová adaptace novely z roku 1959 usiluje originálně o nalezení takových podob filmového jazyka, které by umožnily komunikovat obsahy sdělené sice literárním jazykem, avšak sdělitelné ve svém hlavním směřování i jazykem filmovým. ${ }^{3}$ Jan Otčenášek a režisér Jiř́ Weiss napsali společně scénář, $\mathrm{v}$ němž sáhli k řadě textových úprav. Změnili kupř. i jméno hlavní ženské postavy - rodné jméno Ester nahradili v Čechách běžným dívčím jménem Hanka. V této domácké podobě působí původní židovské jméno Hannah česky a obyčejně, zatímco jméno Ester jednoznačně sugeruje židovský původ a jistou exotičnost. Titul novely i filmové adaptace je aluzí na Shakespearovu tragédii, jejíž rodově a zřejmě i nábožensky motivovaná tragičnost se však v porovnání s rasově motivovanou tragédií Židů za nacistické okupace jeví jako méně děsivá.

Motiv tmy z titulu novely je symbolem období zběsilého teroru, který nacisté rozpoutali po atentátu československých parašutistů na zastupujícího řŕšského protektora Reinharda Heydricha. Otčenáškova novela i Weissův film prozkoumávají s fenomenologickou precizností různé podoby strachu - strach ze zatčení, strach z prozrazení Hančina úkrytu, strach z odvety okupantů aj. Strach postupně ovládá všechny postavy, třebaže v různé míře, jíž odpovídají i různé formy reakce. Obrovskému stresu čelí Pavel, protože je nucen hrát dvojí hru - nejen před cizími lidmi, ale i doma musí předstírat klid a mladickou ležérnost, aby zamaskoval svůj odvážný čin, kterým v tehdejší době ohrožoval celou rodinu (za přechovávání nehlášených osob, zejména židovského původu, hrozil v době heydrichiády všem členům rodiny trest smrti).

Náročnou hlavní mužskou roli Pavla zvládl překvapivě dobře mladý slovenský herec Ivan Mistrík, který musel zvládnout text v češtině. Mistríkův maturant Pavel se přesvědčivě zmítá mezi milostným okouzlením židovskou dívkou a sílícím strachem o život nejen svůj, ale i blízkých lidí. Filmová postava Pavla není tolik svázána ohledy na rodinu, zejména na matku, která je velmi ustrašená (nevidí ráda, když se Pavel baví na ulici s židovským chlapcem, vezme Pavlovi klíč od komůrky, aby nemohl za židovskou dívkou). Představitelé obou hlavních rolí jsou - oproti postavám knižní předlohy - o pět až šest let starší, což v mladém věku není nepodstatný rozdíl (Ivanu Mistríkovi bylo v době natáčení 23 let, Daně Smutné 24 let). Zřejmě i tato okolnost přispěla k dospělejšímu vyznění Pavlovy osobnosti, jeho chování nese výraznější rysy rozhodnosti a samostatnosti. Pavlův ostych překrývá přirozeně působící slušnost - k židovské dívce se chová se samožrejmým respektem.

Dana Smutná v roli Hanky zaujala svou ušlechtile působící fyziognomií, méně již hereckým výrazem. Touha literární židovské dívky Ester po životě se u filmové Hanky projevuje velmi slabě - herečka pronáší své repliky tiše a emocionálně úsporně, budí spíše dojem dospělé a ustrašené ženy. Esteřino židovství je tak ve filmu oslabeno nejen přejmenováním, ale také ztvárněním postavy. Výraznou ženskou postavou je naopak Pavlova matka, u níž doznává film - oproti novele - celé řady změn. Jiřina Šejbalová se této nově pojaté role zhostila se suverenitou, která hlavní ženskou postavu poněkud zastiňuje. Novou filmovou postavou je Pavlův dědeček (ztvárněný Františkem Smolíkem), v němž kontrastuje technický hračička a podivín s nečekaně odvážným člověkem, který se nebojí židovské dívce pomoci. Kolaborantské myšlení a chování rozvíjí ve filmu nová postava paninky Kubiasové (Blanka Bohdanová), jejíž pragmatismus a koketérie s německými vojáky na sebe strhává nemalou část divácké pozornosti.

Filmovou adaptaci zde posuzuji v souladu s pojetím, které prezentuje studie Bubeníček, Petr: Zásahy adaptace. Ke studiu literatury a filmu. In: Timko, Štefan (ed.): Česká literatura a film. Nitra: UKF, $2014,9-41$. 
Režiséru Weissovi se podařilo potlačit některé pozůstatky socialistickorealistické metody projevující se schematickým rozvržením charakterů postav. Pavlova matka, v novele utíkající před realitou k modlitbám, je díky výkonu Jiřiny Šejbalové životnější. Narážky krejčovského tovaryše Čepka na stinné stránky živnostnictví vyznívají ve filmu méně ideologicky, podobně jako majetnické stereotypy Pavlova otce nebo politická orientace malí̌e z podkroví. Režisér Jiří Weiss zdůrazňuje v rozhovoru s Antonínem J. Liehmen z roku 1973 důležitost práce s osobností herce (Liehm 2001, 103): „Naučil jsem se věrit v osobnost před kamerou, což asi souvisí s mými dokumentaristickými začátky [...]. Zázrak filmu je v rekonstrukci (nebo v konstrukci, chcete-li) lidského života. Film zvětšuje lidskou ,blešku' do nadlidských rozměrů a chvění rtů či zamilovaný pohled jsou silnější než rána z děla. Snad proto byl můj pohled, at už záměrně či ne, vždycky mikroskopický, snad až př́lišs. Ale to souvisí s osobností režiséra, který je zároveň obraz i štětec."

Posílení dramatičnosti filmové adaptace dosáhli tvůrci scénáře důležitými proměnami prostorů, v nichž se děj odehrává. Na jedné straně byla zdůrazněna lidská vřelost a funkčnost Pavlova domova, který navzdory protektorátní mizérii dokáže obdivuhodně vytvořit energická maminka. Prostor, v němž se ukrývá židovská dívka, je ve filmu situován přímo do podkroví činžovního domu (v novele jde o komůrku vedle více než kilometr od domova vzdálené otcovy krejčovské dílny, kam Pavel za Ester tajně dochází). Film tak akcentuje riziko, které je s ukrýváním Hanky spojeno. Oproti mlhavému prostředí školy v novele je ve filmu školní prostředí nositelem bližších informací o atentátu na Heydricha a je spojeno se silným strachem z jasně vnímaného odvádění spolužáka gestapem.

Scenáristé dopsali další dějově a vizuálně atraktivní epizody, jejichž kontrastnost dokresluje absurditu doby - např̀. rozhlasové hlášení oznamující spáchání atentátu na Heydricha a vyhlášení stanného práva je kontrapunkticky zasazeno do Pavlovy schůzky se spolužačkou Alenou pobliž Národního divadla. Novým filmovým prostorem je také koupaliště, kde se Pavel potká s Alenou, která se marně snaží zjistit, proč s ní Pavel přestal mluvit. Některé scény jsou pozměněny tak, aby zvýraznily v novele méně kontrastně nastíněné povahové rysy postav (např. v závěru filmu Pavlova pomoc neznámému člověku, jehož manželka rodí a potřebuje svou židovskou dívku ukrýt).

Filmová adaptace se podobně jako knižní předloha vyhýbá verbálnímu hodnocení postav či dějů - nahrazuje racionálně uchopitelné charakteristiky zvukovými projevy, které působí velmi naléhavě. Nepř́jemné zvuky jako střelba z kulometů, jízda vojenských aut, rozhlasové vysílání z pouličních reproduktorů, štěkot psíka kolaborantky Kubiasové nebo varovný křik andulek kontrastují se ztišenými zvukovými projevy postav trpících a mírných, jakými jsou zejména Hanka a Pavlův dědeček.

Vizuální stránka vychází z možností černobílého filmu zachycovat ve světelných kontrastech a odstínech šedi ponurost a postupně až děsivost okupační atmosféry. Tvůrci filmu však nezůstávají u této obecné motivace $\mathrm{k}$ volbě monochromu. V Otčenáškově novele je tma protihráčem, ale i spoluhráčem milenecké dvojice, nikoli pouhou součástí vnějšího prostředí. Tma proniká stále intenzivněji do sociálního prostředí i do mikrosvěta postav - rozežírá je zevnitř, zásadním způsobem poznamenává jejich psychiku. Navíc se neomezuje pouze na konkrétní region, ale v době světové války je do značné míry obecným stavem světa. K reflexi této problematiky je nutný divákův odstup od přemíry vizuálních informací, které zprostředkovává barevný film. Thomas C. Foster zdůrazňuje právě schopnost černobílého filmu umožnit snazší získání odstupu od zobrazovaných dějů (Foster 2017, 137 - 138). Stylizační potenciál černobílého snímku využili tvůrci i k hodnotovému rozvržení postav a dějů. Střihem pak promyšleně stupňují napětí či naopak zpomalují běh událostí, jejichž vyznění většinou není jednoznačné.

Cenzurní zásahy se - podobně jako u řady snímků nové vlny - nevyhnuly ani Weissovu filmu: některé scény byly upraveny, celá závěrečná scéna musela být přetočena, aby odstranila stopy českého antisemitismu (místopředsedovi československé vlády Václavu Kopeckému prý vadily pohledy 
nájemníků, kteří nechtěli mít nic společného s Židy). Režisér Jiří Weiss přibližuje v rozhovoru s Antonínem J. Liehmem pojetí filmové adaptace Otčenáškovy novely (Liehm 2001, 100): „Romeo, Julie a tma byl pro mě film o lidském chování v nebezpečné situaci. A o tom, co se za ně platí. Strach nakonec zvitězí, morálka a všechno ostatní jdou stranou. Taková ta lidská slušnost zemřela. Lidé žijí dál a mají dokonce odvahu kázat ostatním morálku. Když se film promítal establišmentu, ukázal palcem dolù. Obvinili mě, že jsem udělal sionistický film. Nejvíc je pobouřilo, jak obyvatelé domu tiše přihližejí, když odvádějí dèvče na jistou smrt. Musel jsem tu scénu (a několik dalších) přetočit, aby se nežidovské obecenstvo cítilo aspoň trochu líp...".

Stejně jako Otčenáškova novela usiluje i Weissův film o subjektivní pohled několika málo postav na období nacistické okupace - představuje tak zajímavý prolog k československé vlně 60. let, v níž kolektivismus a nezpochybnitelné pravdy oficiální ideologie postupně střídá důraz na individuální prožitky a relativizující výklad národní minulosti. Ve zmíněném rozhovoru říká Jiří Weiss (Liehm 2001, 103): „Filmy s okupační tematikou jsou první, v nichž lze útočit na filosofii establišmentu - začí s destrukcí mýtů. Producent, tedy stát, je zticha, protože jeho hlavní kritérium - stále neurčitější ideologie - zůstává nedotčeno. Protože známý rámec a hrdinové v něm zůstali nedotčeni, nevšimne si producent nad scénářem, že se změnilo cosi podstatného, že žánr se stal nositelem nových myšlenek a pochyb, že došlo k relativizaci mýtü."

Komorní milostné drama Romeo, Julie a tma není ani v novele Jana Otčenáška, ani ve filmové adaptaci Jiř́ho Weisse pouhou dobově aktualizovanou aluzí na světoznámou tragédii renesančního dramatika. V kontrastu k Shakesperově hře, kde protihráčem byla individuální či rodinná omezenost a intolerance, je v dramatu z nacistické okupace situace milenců vystupňovaná do krajnosti: tváří v tvář všudypřítomné smrti sebevětší láska a individuální obětavost nestačí, ochromí-li většinu obyčejných lidí lhostejnost nebo strach.

Autoři prózy a filmové adaptace předvedli věčně se opakující tragédii na osudu národa pronásledovaného po tisíciletí - učinili tak umělecky působivou formou a navíc v režimu, který předstíral péči o humanistické hodnoty a soustavně falšoval starší a zejména moderní dějiny. Vedle próz Arnošta Lustiga a jejich filmových adaptací tak Otčenáškův a Weissův počin štastně předznamenal novou vlnu literární a filmové tvorby v Československu šedesátých let tím, že stylotvorné úsilí nevnímal pouze v rovině literární a filmové estetiky, ale spojil je s hledáním podstatných etických hodnot.

\section{SUMMARY}

The article analyzed the novel by Jan Otčenášek Romeo, Julie a tma (Romeo, Juliet and Darkness) and its film adaptation into the feature film of the same name. The author of the novel, together with the director Jiři Weiss, wrote a screenplay in which editing the text shifts the meaning of prose to greater dynamism and emphasizes ethical issues. The illusions of Shakespeare's tragedy and the motive of darkness are ambiguous symbols that evoke the intensity of love and fear in the growing danger of World War II. Weiss's film seeks a subjective view of a few characters about the period of the Nazi occupation - it belongs to the Czechoslovak wave of the 1960s, in which collectivism and the undeniable truths of official ideology gradually alternate the emphasis on individual experiences and a relativizing interpretation of the national past.

\section{LITERATURA}

Blažíček, Přemysl, 1998. Jan Otčenášek (slovníkové heslo). In: Janoušek, Pavel a kol.: Slovník českých spisovatelů od roku 1945. Díl 2. Praha: ÚČL AVČR - Nakladatelství Brána - Knižní klub, $159-161$. 
Bubeníček, Petr, 2014. Zásahy adaptace. Ke studiu literatury a filmu. In: Timko, Štefan (ed.): Česká literatura a film. Nitra: UKF, 9 - 41.

Foster, Thomas C., 2017. Jak číst film. Brno: Host.

Haman, Aleš, 1961. O tak zvané „druhé vlně“ válečné prózy v naší současné literatuře. In: Česká literatura, roč. 9, č. 4, $513-520$.

Holý, Jiří, 1998. Tání. In: Lehár, Jan - Stich, Alexandr - Janáčková, Jaroslava - Holý, Jiří: Česká literatura od počátků k dnešku. Praha: Nakladatelství Lidové noviny, $754-767$.

Janoušek, Pavel a kol., 2012. Přehledné dějiny české literatury 1945-1989. Praha: Academia.

Komárek, Karel, 1994. Jan Otčenášek: Romeo, Julie a tma. In: Dokoupil, Blahoslav - Zelinský, Miroslav (eds.): Slovník české prózy 1945-1994. Ostrava: Sfinga, 276 - 278.

Kučera, Petr, 2018. Spalovač mrtvol Ladislava Fukse ve filmové adaptaci Juraje Herze. In: Timko, Štefan (ed.): Česká literatura a film V. Nitra: UKF, 54 - 75.

Liehm, Antonín J., 2001. Ostře sledované filmy. Československá zkušenost. Praha: Národní filmový archiv.

Machala, Lubomír a kol., 2015. Panorama české literatury. 1. díl (do roku 1989). Praha: Euromedia Group - Knižní klub.

Orten, Jiří, 1993. Spisy II. Žíhaná kniha. Praha: Český spisovatel.

Otčenášek, Jan, 2014. Romeo, Julie a tma. Praha: Dobrovský (edice Omega).

\section{CITOVANÝ FILM}

Romeo, Julie a tma (r. Jiří Weiss, Československo, 1959).

\section{KONTAKT}

doc. Dr. Petr Kučera, Ph.D.

Katedra germanistiky a slavistiky

Filozofická fakulta ZČU v Plzni

Riegrova 11

30614 Plzeň

Česká republika

pekucera@kgs.zcu.cz 